\title{
Sandwich Structured Electrolyte of High Sputtering Efficiency for All-solid-state Electrochromic Devices by Optical Design
}

\author{
JIA Hanxiang ${ }^{1,2}$, SHAO Zewei ${ }^{1,2}$, HUANG Aibin ${ }^{1}$, JIN Pingshi ${ }^{1}$, CAO Xun ${ }^{1}$
}

(1. State Key Laboratory of High Performance Ceramics and Superfine Microstructure, Shanghai Institute of Ceramics, Chinese Academy of Sciences, Shanghai 200050, China; 2. University of Chinese Academy of Sciences, Beijing 100049, China)

\begin{abstract}
The all-solid-state electrochromic devices (ECDs) have been widely developed for energy-saving windows, screen displays, multi-functional energy storage devices due to their characteristics such as large optical contrast, fast switching speed and good cycle stability. However, traditional all-solid-state ECDs based on monolayer electrolyte system are often limited by ordinary optical transmittance and inadequate sputtering efficiency. Herein, the all-solidstate ECDs integrated with $\mathrm{LiAlO}_{x} / \mathrm{Ta}_{2} \mathrm{O}_{5} / \mathrm{LiAlO}_{x}$ (ATA) sandwich structured electrolyte were successfully fabricated by reactive DC magnetron sputtering technique. By means of introduction of ATA sandwich structured electrolyte, the prepared ECDs with seven layer (ITO/NiO/LiAlO $/ \mathrm{Ta}_{2} \mathrm{O}_{5} / \mathrm{LiAlO}_{x} / \mathrm{WO}_{3} / \mathrm{ITO}$ ) was endowed with superfine optical transmittance and substantial sputtering efficiency simultaneously. The ATA-based ECDs realized satisfactory coloration efficiency of $79.6 \mathrm{~cm}^{2} / \mathrm{C}$, fast switching speed as short as $1.9 \mathrm{~s}$ for coloring and $1.6 \mathrm{~s}$ for bleaching, and excellent cycling stability over hundreds of cycles. Furthermore, ATA sandwich structured electrolyte makes full use of the excellent ionic conductivity and stability of $\mathrm{Ta}_{2} \mathrm{O}_{5}$, as well as enough lithium ions to meet the demand for fast color switching. Hence, ATA-based all-solid-state ECDs by continuous DC sputtering is expected to provide effective guidance for the mass production and practical application of the high-performance ECDs.
\end{abstract}

Key words: inorganic all-solid-state; electrochromic device; multilayer electrolyte; sputtering efficiency; optical design

With the enhancement of people's awareness of energy conservation and environmental protection, electrochromic devices (ECDs), used in buildings and vehicles have attracted increasing attention in recent years ${ }^{[1-2]}$. Compared to other chromogenic materials, electrochromism is capable of reversibly switching between colored and bleached states corresponding to internal ion inserting and extracting ${ }^{[3-4]}$. Taking advantage of that, ECDs play a major role in many fields, such as image display ${ }^{[5]}$, smart windows $^{[6]}$ and stealth ${ }^{[7]}$, which are expected to realize industrialization ahead of other chromogenic materials. However, the application of ECDs are limited due to their low fabrication efficiency, unaffordable cost and complex packaging technique. Therefore, study on allsolid-state ECDs with both high performance and high sputtering efficiency has gradually become a trend ${ }^{[8-10]}$.

Some metrics are important factors affecting the performance of all-solid-state ECDs, such as optical contrast, cycle stability, especially sputtering efficiency and switching speed ${ }^{[11]}$. Inorganic all-solid-state ECDs are typically composed of five superimposed layers ${ }^{[12]}$ : electrolyte layer is laminated between two EC layers, such as cathodic colored $\mathrm{WO}_{3}$ and anodic colored NiO, individually connected with a transparent conductive layer. However, such typical five-layer ECDs based on monolayer electrolyte system are often limited by ordinary optical transmittance and inadequate sputtering efficiency, which is adverse to practical application and mass production. Generally, the magnetron sputtering efficiency of ceramic target with RF power supply is

Received date: 2020-11-05 Revised date: 2020-11-25; Published online: 2020-12-10

Foundation item: National Natural Science Foundation of China (51972328, 51903244); Youth Innovation Promotion Association, Chinese Academy of Sciences (2018288); Science Foundation for Youth Scholar of State Key Laboratory of High Performance Ceramics and Superfine Microstructures (SKL201703); Shanghai Pujiang Program (18PJD051); Key Research and Development Plan of Anhui Province (1804a09020061); Shanghai Sailing Program (19YF1454300)

Biography: JIA Hanxiang(1993-), male, PhD candidate. E-mail: jiahanxiang@student.sic.ac.cn

贾汉祥(1993-), 男, 博士研究生. E-mail: jiahanxiang@student.sic.ac.cn

Corresponding author: CAO Xun, professor. E-mail: cxun@mail.sic.ac.cn

曹 逊, 研究员. E-mail: cxun@mail.sic.ac.cn 
unsatisfactory $^{[13-14]}$. In contrast, there are few reports about solid electrolyte sputtered directly by metal or alloy targets, which can be applied to large-scale coating process ${ }^{[15]}$. Furthermore, low optical transmittance of traditional all-solid-state ECDs is sometimes far from meeting the standards for practical applications ${ }^{[16-17]}$. Optical design for anti-reflection simulation of multilayer electrolyte film can be applied to realize the theoretical maximum value of optical transmittance ${ }^{[18]}$. Therefore, it is necessary to develop ECDs with a given multilayer structure which have high sputtering efficiency, high optical transmittance and satisfactory service performance ${ }^{[19-20]}$.

Taking the above factors into consideration, $\mathrm{LiAlO}_{x} /$ $\mathrm{Ta}_{2} \mathrm{O}_{5} / \mathrm{LiAlO}_{x}$ (ATA) sandwich structured electrolyte with $\mathrm{LiAlO}_{x}$ supplying enough lithium ions and $\mathrm{Ta}_{2} \mathrm{O}_{5}$ serving as ion transport layer is requisite for optimizing the properties of the novel structured ECDs. The electronblocking behavior, high ionic conductivity and chemical stability of $\mathrm{Ta}_{2} \mathrm{O}_{5}$ makes it an ideal ion transport layer in ECDs. Meanwhile, $\mathrm{LiAlO}_{x}$ holds both high optical transmittance and ionic conductivity. Due to the difference of refractive index between $\mathrm{LiAlO}_{x}$ and $\mathrm{Ta}_{2} \mathrm{O}_{5}$, the sandwich structure electrolyte with alternating high and low refractive index can be designed, which is expected to improve the transmittance using the anti-reflection principle ${ }^{[21]}$. Thus, the structure makes full use of the excellent ionic conductivity and stability of $\mathrm{Ta}_{2} \mathrm{O}_{5}$, as well as enough lithium ions to meet the demand for fast color switching.

In this study, a seven-layer all-solid-state ECD (ITO/NiO/LiAlO ${ }_{x} / \mathrm{Ta}_{2} \mathrm{O}_{5} / \mathrm{LiAlO}_{x} / \mathrm{WO}_{3} / \mathrm{ITO}$ ) incorporated with ATA sandwich structured electrolyte of high sputtering efficiency, high optical transmittance and satisfactory coloration efficiency was designed. Due to effective lithium ions immigration channels provided by ATA sandwich structured electrolyte, the ECD hires remarkably improved switching speed and optimized optical transmittance. Moreover, the sputtering efficiency of ECDs was greatly improved by means of DC continuous magnetron sputtering using metal or alloy targets. The ATA based all-solid-state ECDs by optical design bring a further insight into the mass production and marketization of high-performance ECDs.

\section{Experimental}

\subsection{Materials and synthesis}

$\mathrm{NiO}$ film and $\mathrm{LiAlO}_{x} / \mathrm{Ta}_{2} \mathrm{O}_{5} / \mathrm{LiAlO}_{x}$ sandwich structured electrolyte were deposited on $20 \mathrm{~mm} \times 20 \mathrm{~mm}$ indium tin oxide (ITO) glass substrates in sequence via reactive DC magnetron sputtering. $\mathrm{LiAlO}_{x}$ film was conducted in the flow of $\mathrm{Ar} / \mathrm{O}_{2}$ (40 sccm/10 sccm). The sputtering used Li-Al alloy target $(99.9 \%$, diameter of $10.16 \mathrm{~cm})$ with
$200 \mathrm{~W}$ DC power for $45 \mathrm{~min}$ at room temperature (RT). Then the middle layer of $\mathrm{Ta}_{2} \mathrm{O}_{5}$ was deposited at RT using Ta metal target $(99.9 \%$, diameter of $10.16 \mathrm{~cm})$. The sputtering was performed under the condition of $200 \mathrm{~W}$ DC power and $\mathrm{Ar} / \mathrm{O}_{2}$ ratio of 45:5. For the next step, an amorphous $\mathrm{WO}_{x}$ film was deposited in quick succession. Finally, a layer of ITO film was deposited on top of it acting as a top electrode. The detailed deposition parameters of each layer was simulated for max optimization of optical performance in Table 1.

\subsection{Characterizations}

The section microstructure of ECDs was shown in the cross-section micrographs by field-emission scanning electron microscope (FESEM, FEI Magellan 400). To monitor the surface roughness of monolayer electrolyte film, atomic force microscope (AFM, SII Nano Technology Ltd, Nanonavi П) was examined. Later, the electrochromic property indexes including coloration efficiency, optical contrast, and cycle durability were studied by a CS350 electrochemical workstation (Corrtest, Wuhan). Lastly, UV/Vis/NIR Spectrometer (Hitachi, UV-4100) was used to characterize the in-situ transmittance spectrum of ECDs ranging from 350 to $2600 \mathrm{~nm}$ with the scanning speed of $1200 \mathrm{~nm} / \mathrm{min}$. In addition, optical modeling was executed via software of Essential Macleod to optimize the experimental spectra, based on the theory of optical interference by utilizing the optical constants of $\mathrm{LiAlO}_{x}$ and $\mathrm{Ta}_{2} \mathrm{O}_{5}$.

\section{Results and discussion}

\subsection{Designed microstructure of ECDs}

The surface microstructure of as-prepared electrolyte was characterized by AFM. The as-deposited $\mathrm{LiAlO}_{x}$ and $\mathrm{Ta}_{2} \mathrm{O}_{5}$ films exhibited smooth surface with root-meansquare roughness (RMS) of 0.45 and $1.14 \mathrm{~nm}$, respectively (Fig. 1(a-b)). The ECD containing $\mathrm{LiAlO}_{x} /$ $\mathrm{Ta}_{2} \mathrm{O}_{5} / \mathrm{LiAlO}_{x}$ sandwiched electrolyte was fabricated by optical optimization design. The film thickness, local enlarged view and corresponding element distribution of each layer in ECDs can be observed in Fig. 1(c, d, f). In Fig. 1(f), the element distribution diagram corresponds

Table 1 Sputtering parameters for each layer of ECDs

\begin{tabular}{|c|c|c|c|c|c|}
\hline Layer & Target & ssure & $Q_{\mathrm{Ar}}: Q_{\mathrm{O}_{2}}$ & Power/W & Thickness/nm \\
\hline $\mathrm{LiAlO}_{x}{ }^{\mathrm{a}}$ & Li-Al & 2.0 & $40: 10$ & 200 & $\sim 100$ \\
\hline $\mathrm{Ta}_{2} \mathrm{O}_{5}$ & Тa & 0.7 & $45: 5$ & 200 & $\sim 200$ \\
\hline $\operatorname{LiAlO}_{x}^{\mathrm{b}}$ & $\mathrm{Li}-\mathrm{Al}$ & 2.0 & $40: 10$ & 200 & $\sim 100$ \\
\hline $\mathrm{WO}_{x}$ & $\mathrm{~W}$ & 1.0 & $47: 3$ & 70 & 400 \\
\hline $\mathrm{NiO}$ & $\mathrm{Ni}$ & 1.0 & $40: 10$ & 100 & 150 \\
\hline ITO & ITO & 0.3 & $100: 0$ & 140 & 400 \\
\hline
\end{tabular}

a: Upper layer; b: Lower layer 

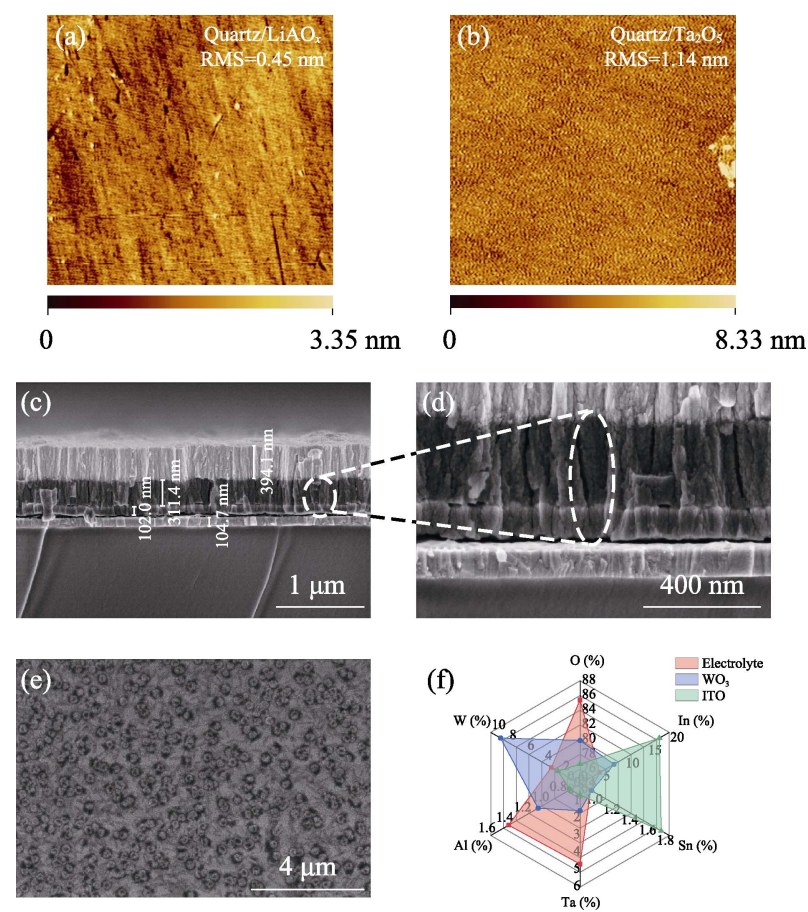

Fig. 1 AFM image of $\mathrm{LiAlO}_{x}$ layer (a) and $\mathrm{Ta}_{2} \mathrm{O}_{5}$ layer (b) of sandwich structured electrolyte (ATA), cross-section SEM image of ATA (c) and partial enlarged detail of it (d), surface SEM image of ATA (e), and element distribution of cross-section of ECDs (f)

to intuitive expression for the cross-section EDS of ECDs, which represented the element distribution of each layer collated with the SEM photographs in Fig. 1(c). The three middle layers consist of $\mathrm{LiAlO}_{x} / \mathrm{Ta}_{2} \mathrm{O}_{5} / \mathrm{LiAlO}_{x}$ sandwich structure with the thickness of nearly 100, 200 and
$100 \mathrm{~nm}$, respectively. Besides, surface SEM image of ATA electrolyte display the view of isolated island particles (Fig. 1(e), which indicates the loose porous structure of $\mathrm{LiAlO}_{x}$ layer. Thus, the ATA electrolyte constructed the effective conductive channel, which made the most of its excellent properties of ion conduction and stability.

\subsection{Optical characterization and simulation of ECDs}

To study $\mathrm{O}_{2}$ flow ratio dependent optical transmittance of $\mathrm{Ta}_{2} \mathrm{O}_{5}$, different $\mathrm{O}_{2}$ contents $\left(\mathrm{O}_{2} /\left(\mathrm{Ar}+\mathrm{O}_{2}\right)\right)(0,5 \%, 10 \%$ and $15 \%$ ) were set for $\mathrm{Ta}_{2} \mathrm{O}_{5}$ sputtering in Fig. 2(a). When the $\mathrm{O}_{2}$ ratio corresponded to $10 \%$, its optical transmittance was best optimized, which was applied to the sputtering of ATA electrolyte. Fig. 2(b) shows the in-situ transmittance spectra during 350-2600 nm with the applied voltage varying from $-3 \mathrm{~V}$ to $3 \mathrm{~V}$ for ECDs. The initial state was highly bleached. With the increase of positive voltage, the optical transmittance decreased gradually due to its EC coloration effect. Until the bias reaches $3 \mathrm{~V}$, the optical transmittance decreased even below 10\%. Especially, ECDs presented excellent color retention as the external voltage was removed. Finally, ECDs returned to its original bleached state when the reverse voltage was applied.

In addition, optical simulation was performed for $\mathrm{LiAlO}_{x} / \mathrm{Ta}_{2} \mathrm{O}_{5} / \mathrm{LiAlO}_{x}$ sandwich structured electrolyte. The optical constants ( $n$ and $k$ ) of $\mathrm{LiAlO}_{x}$ and $\mathrm{Ta}_{2} \mathrm{O}_{5}$ were used for calculation, which was made for different thickness combinations of $\mathrm{LiAlO}_{x}$ and $\mathrm{Ta}_{2} \mathrm{O}_{5}$, and an optimized structure was chosen upon the maximum integrated luminous transmittance. Then the experimental and
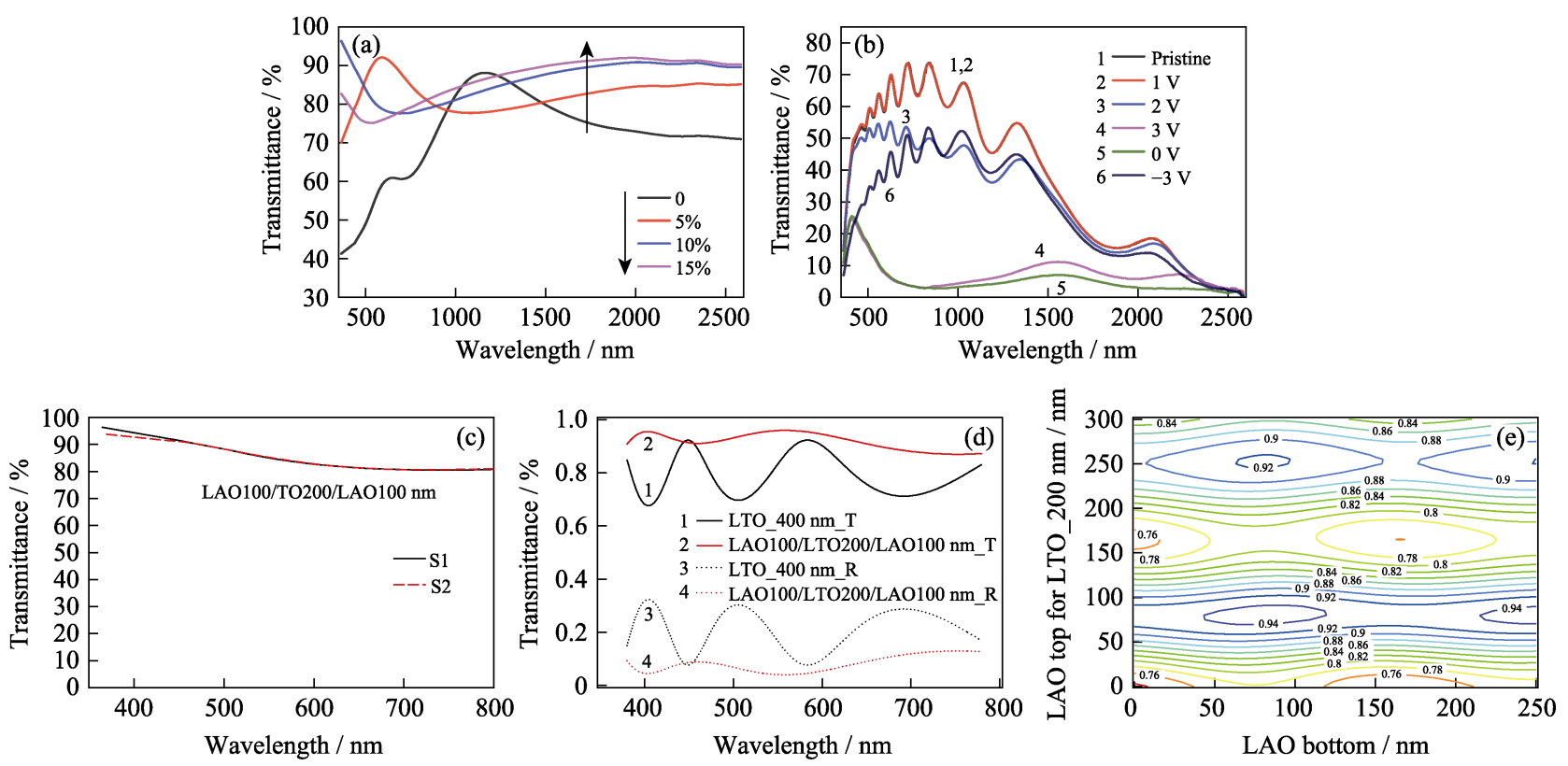

Fig. 2 UV-Vis-NIR spectra (a) of $\mathrm{Ta}_{2} \mathrm{O}_{5}$ films deposited under different $\mathrm{O}_{2}$ ratios of $0,5 \%, 10 \%, 15 \%$, respectively, optical modulation (b) of ECDs during $-3 \mathrm{~V}$ to $3 \mathrm{~V}$, experimental (c) and calculated (d) transmittance spectra of sandwich structured electrolyte, in which S1 and S2 refer to two parallel samples, LAO refers to $\mathrm{LiAlO}_{x}$, TO refer to $\mathrm{Ta}_{2} \mathrm{O}_{5}$, and LTO refer to $\mathrm{Li}^{+}$-inserted $\mathrm{Ta}_{2} \mathrm{O}_{5}$, optical design for optimized thickness of ATA via software of Essential Macleod (e) 
calculated transmittance spectra of sandwich structured electrolyte were tested (Fig. 2(c-d)), which fit well with each other. By means of the optical calculation via software of Essential Macleod, the optical transmittance of ATA reach over $90 \%$ at the thickness of $100 \mathrm{~nm} /$ $200 \mathrm{~nm} / 100 \mathrm{~nm}$, which is superior to that of $\mathrm{LiTaO}_{3}$ at the same thickness. The structure of ATA electrolyte was optimized with the optical constants of $\mathrm{LiAlO}_{x}$ and $\mathrm{Ta}_{2} \mathrm{O}_{5}$ via software of Essential Macleod in Fig. 2(e), which shows the relationship between the luminous transmittance of ATA electrolyte and the film thickness of top and bottom $\mathrm{LiAlO}_{x}$ layer, that is, " $\mathrm{LiAlO}_{x}$ (bottom layer, thickness $\left.t_{1}\right) / \mathrm{Ta}_{2} \mathrm{O}_{5}(200 \mathrm{~nm}) / \mathrm{LiAlO}_{x}$ (top layer, thickness $\left.t_{2}\right)$ ". When $t_{1}=t_{2}=0$, namely only $\mathrm{Ta}_{2} \mathrm{O}_{5}$ monolayer, the visible light transmittance corresponds to the lowest trough. When the top and bottom layer of $\mathrm{LiAlO}_{x}$ was introduced, the visible light transmittance increases in a wavy manner and reaches the maximum value over $90 \%$ under certain conditions $\left(t_{1}=t_{2}=100 \mathrm{~nm}\right)$. Additionally, the designed structure was calculated according to the transparent state of $\mathrm{Ta}_{2} \mathrm{O}_{5}$ when lithium ions locate on the side of electrochromic layer under electric field. Therefore, $\mathrm{LiTaO}_{3}$ (LTO) is equivalent to $\mathrm{Ta}_{2} \mathrm{O}_{5}$ (TO), which has little difference in optical constants without lithium ions.

\subsection{Comparison of sputtering efficiency for several typical functional layers}

One of the highlights of this work is to summarize the sputtering efficiency of electrochromic devices, which is rarely summarized in previous work. Generally speaking, DC power sputtering is relatively more efficient than RF power in the industrial production ${ }^{[22]}$. However, there lacks of a quantitative comparison to guide the cost and efficiency in mass production. Taking the above into consideration, a continuous sputtering process of metal or alloy targets using DC power supply was proposed in this work. As displayed in Fig. 3, thin films of $\mathrm{WO}_{x}, \mathrm{NiO}$, $\mathrm{LiAlO}_{x}, \mathrm{LiTaO}_{3}$ and $\mathrm{Ta}_{2} \mathrm{O}_{5}$ were sputtered using DC and RF power supply, respectively. Here, we introduce a parameter, sputtering efficiency, which can be defined as the ratio of sputtering rate to power density. In Table 2, the sputtering efficiency of DC supply are obviously improved related to that of RF supply for each deposited layer. Especially, the sputtering efficiency of $\mathrm{WO}_{x}$ increased by nearly 14 times from RF to DC sputtering, mutually verified with Fig. 3.

\subsection{Electrochemical property of the ATA based ECDs}

As shown in Fig. 4(a), by means of optical design, the optical transmittance of the sandwich structured electrolyte (ATA) has been greatly improved on the premise that the ionic conductivity is not lower than that of $\mathrm{LiTaO}_{3}$ at the same thickness. The designed ATA based ECDs have satisfactory coloring efficiency of $79.6 \mathrm{~cm}^{2} / \mathrm{C}$ while changing color reversibly (Fig. 4(b)). The inset of Fig. 4(b) reflects reversible color change between the bleached and colored states of the as-prepared ECD with the size of $20 \mathrm{~mm} \times 20 \mathrm{~mm}$. Moreover, its response time for coloring and bleaching is as short as 1.9 and $1.6 \mathrm{~s}$, respectively (Fig. 4(c)), which is mainly due to the convenient transport channels and rich ion reservation of ATA sandwich structured electrolyte. At the meantime, it keeps stable optical modulation after 200 cycles with in-situ testing units fixed wavelength at $630 \mathrm{~nm}$ (Fig. 4(d)).

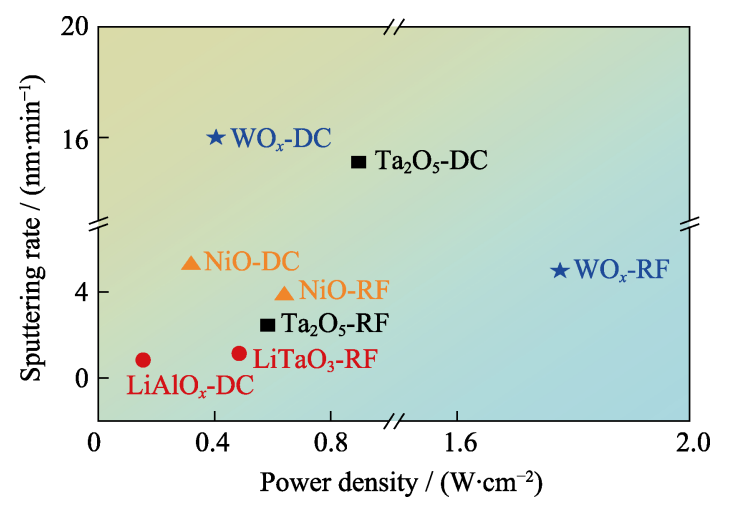

Fig. 3 Comparison of sputtering efficiency parameters for several typical layers of ECDs

Table 2 Comparison of sputtering efficiency for several typical systems

\begin{tabular}{|c|c|c|c|c|c|c|}
\hline Layer & Target & Power supply & Power density $/\left(\mathrm{W} \cdot \mathrm{cm}^{-2}\right)$ & $\begin{array}{l}\text { Sputtering rate/ } \\
\left(\mathrm{nm} \cdot \mathrm{min}^{-1}\right)\end{array}$ & $\begin{array}{l}\text { Sputtering efficiency/ } \\
\left(\left(\mathrm{nm} \cdot \mathrm{min}^{-1}\right) /\left(\mathrm{W} \cdot \mathrm{cm}^{-2}\right)\right)\end{array}$ & Ref. \\
\hline \multirow[t]{2}{*}{$\mathrm{Ta}_{2} \mathrm{O}_{5}$} & $\mathrm{Ta}_{2} \mathrm{O}_{5}$ & $\mathrm{RF}$ & 0.57 & 2.7 & 4.74 & [23] \\
\hline & $\mathrm{Ta}$ & DC & 0.89 & 15 & 16.85 & This work \\
\hline $\mathrm{LiTaO}_{3}$ & $\mathrm{LiTaO}_{3}$ & $\mathrm{RF}$ & 0.48 & 1.2 & 2.50 & {$[24]$} \\
\hline $\mathrm{LiAlO}_{x}$ & $\mathrm{Li}-\mathrm{Al}$ & DC & 0.16 & 1 & 6.25 & This work \\
\hline \multirow[t]{2}{*}{$\mathrm{WO}_{x}$} & $\mathrm{WO}_{3}$ & $\mathrm{RF}$ & 1.78 & 5 & 2.81 & [25] \\
\hline & W & DC & 0.40 & 16 & 40 & This work \\
\hline \multirow[t]{2}{*}{$\mathrm{NiO}$} & $\mathrm{NiO}$ & $\mathrm{RF}$ & 0.64 & 3.6 & 5.63 & [26] \\
\hline & $\mathrm{Ni}$ & DC & 0.32 & 5 & 15.63 & This work \\
\hline
\end{tabular}



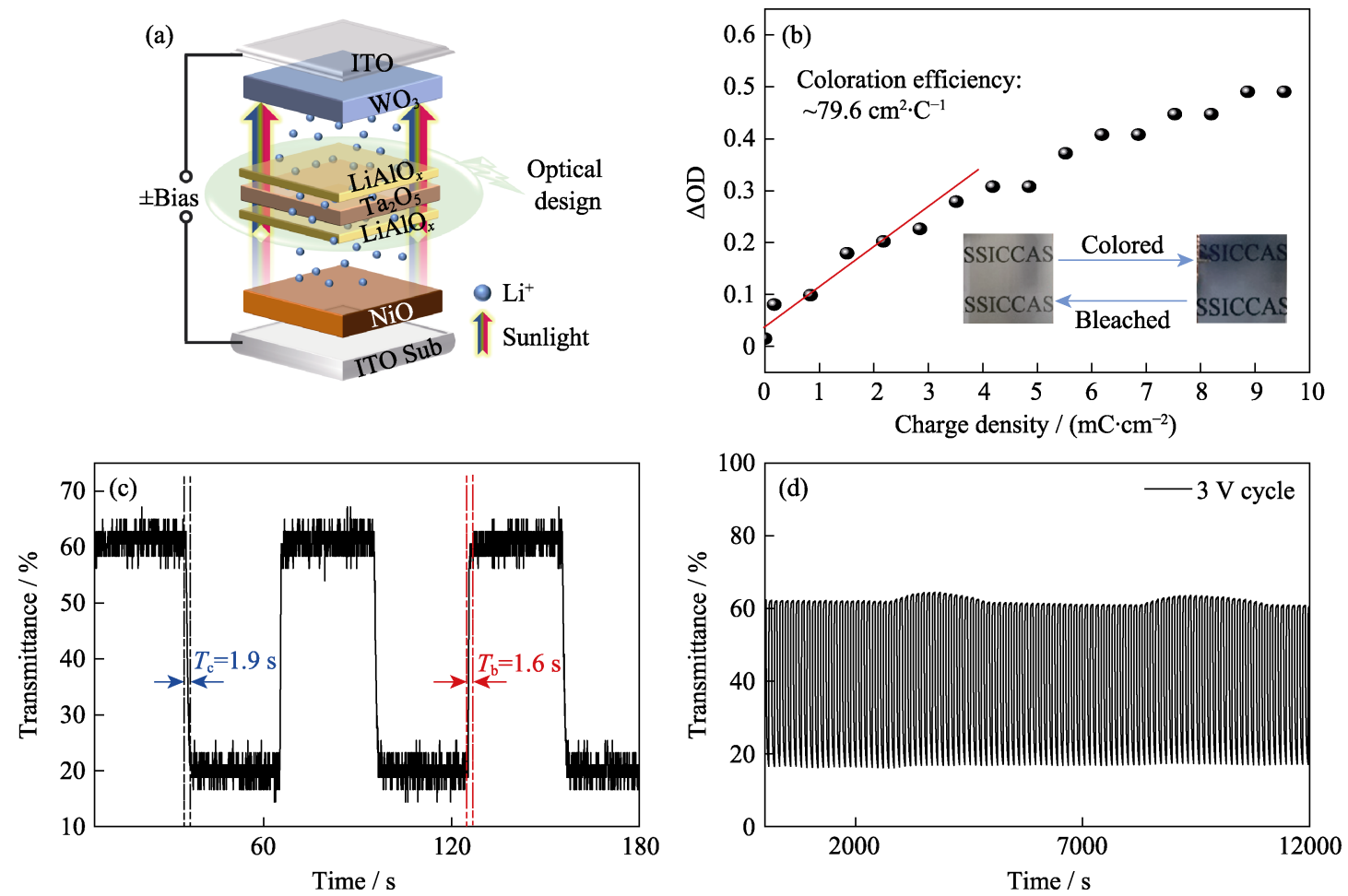

Fig. 4 Schematic diagram of the ATA based seven-layer all-solid-state ECDs by optical design (a), color efficiency of ECDs with inset correspond to EC reaction of ECDs (b), switching speed (c) and cycle durability test (d) of ECDs

\section{Conclusions}

In summary, we have developed the sandwich structured electrolyte with high transparency of luminous transmittance over $90 \%$ and remarkable sputtering efficiency by DC reactive magnetron sputtering using alloy and metal target. Additionally, ATA sandwich structured electrolyte as the ion conducting layer has been introduced into a seven-layer all-solid-state ECD consisting of ITO/NiO/LiAlO $/ \mathrm{Ta}_{2} \mathrm{O}_{5} / \mathrm{LiAlO}_{x} / \mathrm{WO}_{3} / \mathrm{ITO}$. Furthermore, ATA-based ECDs realized satisfactory coloration efficiency of $79.6 \mathrm{~cm}^{2} / \mathrm{C}$, fast switching speed as short as $1.9 \mathrm{~s}$ for coloring and $1.6 \mathrm{~s}$ for bleaching, and excellent cycling stability over hundreds of cycles. Hence, ATA-based ECDs by optical design are expected to realize mass production and practical application in the near future.

\section{References:}

[1] EH A L S, TAN A W M, CHENG X, et al. Recent advances in flexible electrochromic devices: prerequisites, challenges, and prospects. Energy Technology, 2018, 6(1): 33-45.

[2] JIA H X, CAO X, JIN P S. Advances in inorganic all-solid-state electrochromic materials and devices. Journal of Inorganic Materials, 2020, 35(5): 511-524.

[3] THUMMAVICHAI K, XIA Y D, ZHU Y Q. Recent progress in chromogenic research of tungsten oxides towards energy-related applications. Progress in Materials Science, 2017, 88: 281-324.

[4] YUE Y F, LI H Z, LI K R, et al. Preparation and properties of $\mathrm{NiO} / \mathrm{Pb}$ hybrid electrochromic film. Journal of Inorganic Materials,
2017, 32(9): 949-954.

[5] CAO X, LAU C, LIU Y, et al. Fully screen-printed, large-area, and flexible active-matrix electrochromic displays using carbon nanotube thin-film transistors. ACS Nano, 2016, 10(11): 9816-9822.

[6] ZHANG S L, CAO S, ZHANG T R, et al. $\mathrm{Al}^{3+}$ intercalation/ deintercalation-enabled dual-band electrochromic smart windows with a high optical modulation, quick response and long cycle life. Energy \& Environmental Science, 2018, 11(10): 2884-2892.

[7] LI G, ZHANG S, GUO C, et al. Absorption and electrochromic modulation of near-infrared light: realized by tungsten suboxide. Nanoscale, 2016, 8(18): 9861-9868.

[8] SHAPLOV A S, PONKRATOV D O, AUBERT P H, et al. A first truly all-solid state organic electrochromic device based on polymeric ionic liquids. Chemical Communications, 2014, 50(24): 3191-3193.

[9] WANG M C, HSIEH M H, CHEN Y C, et al. All-solid-state electrochromic device integrated with near-IR blocking layer for image sensor and energy-saving glass application. Applied Physics Letters, 2016, 109(12): 123501.

[10] XIE L L, ZHAO S W, ZHU Y, et al. High performance and excellent stability of all-solid-state electrochromic devices based on a $\mathrm{Li}_{1.85} \mathrm{AlO}_{z}$ ion conducting layer. ACS Sustainable Chemistry \& Engineering, 2019, 7(20): 17390-17396.

[11] ZHU Y, XIE L L, CHANG T C, et al. High performance all-solid-state electrochromic device based on $\mathrm{Li}_{x} \mathrm{NiO}_{y}$ layer with gradient Li distribution. Electrochimica Acta, 2019, 317: 10-16.

[12] ZHOU D, XIE D, XIA X H, et al. All-solid-state electrochromic devices based on $\mathrm{WO}_{3} \mid \mathrm{NiO}$ films: material developments and future applications. Science China-Chemistry, 2017, 60(1): 3-12.

[13] ZHANG X, ZHAO Y, LING Q, et al. Study on preparation of LSTP thin film electrolyte by RF magnetron sputtering and electrical properties. Journal of Materials Science: Materials in Electronics, 2020, 31(1): 542-547.

[14] XIAO D L, TONG J, FENG Y, et al. Improved performance of 
all-solid-state lithium batteries using LiPON electrolyte prepared with Li-rich sputtering target. Solid State Ionics, 2018, 324: 202-206.

[15] TAJIMA K, YAMADA Y, BAO S, et al. Solid electrolyte of tantalum oxide thin film deposited by reactive DC and RF magnetron sputtering for all-solid-state switchable mirror glass. Solar Energy Materials and Solar Cells, 2008, 92(2): 120-125.

[16] CUCE E, RIFFAT S B J R, REVIEWS S E. A state-of-the-art review on innovative glazing technologies. Renewable Sustainable Energy Reviews, 2015, 41: 695-714.

[17] BAETENS R, JELLE B P, GUSTAVSEN A. Properties, requirements and possibilities of smart windows for dynamic daylight and solar energy control in buildings: a state-of-the-art review. Solar Energy Materials and Solar Cells, 2010, 94(2): 87-105.

[18] ZHAO Y, XU R, ZHANG X, et al. Simulation of smart windows in the $\mathrm{ZnO} / \mathrm{VO}_{2} / \mathrm{ZnS}$ sandwiched structure with improved thermochromic properties. Energy Buildings, 2013, 66: 545-552.

[19] YU G, XIE X, PAN L, et al. Hybrid nanostructured materials for high-performance electrochemical capacitors. Nano Energy, 2013, 2(2): 213-234.

[20] GRANQVIST C G, LANSÅKER P, MLYUKA N, et al. Progress in chromogenics: new results for electrochromic and thermochromic materials and devices. Solar Energy Materials and Solar Cells,
2009, 93(12): 2032-2039.

[21] JIN P, XU G, TAZAWA M, et al. Design, formation and characterization of a novel multifunctional window with $\mathrm{VO}_{2}$ and $\mathrm{TiO}_{2}$ coatings. Applied Physics A, 2003, 77(3/4): 455-459.

[22] TAJIMA K, HOTTA H, YAMADA Y, et al. Fabrication of solid electrolyte $\mathrm{Ta}_{2} \mathrm{O}_{5}$ thin film by reactive DC magnetron sputtering suitable for electrochromic all-solid-state switchable mirror glass. Journal of the Ceramic Society of Japan, 2011, 119(1385): 76-80.

[23] CORBELLA C. Influence of the porosity of RF sputtered $\mathrm{Ta}_{2} \mathrm{O}_{5}$ thin films on their optical properties for electrochromic applications. Solid State Ionics, 2003, 165(1-4): 15-22.

[24] SUN B, WANG J, GOU J, et al. Influence of thermal annealing on structural and optical properties of RF-sputtered $\mathrm{LiTaO}_{3}$ thin films. Materials Research Express, 2018, 6(2): 026405.

[25] KALAGI S S, MALI S S, DALAVI D S, et al. Transmission attenuation and chromic contrast characterization of R.F. sputtered $\mathrm{WO}_{3}$ thin films for electrochromic device applications. Electrochimica Acta, 2012, 85: 501-508.

[26] AHN K S, NAH Y C, YUM J H, et al. The effect of $\mathrm{Ar} / \mathrm{O}_{2}$ ratio on electrochromic response time of $\mathrm{Ni}$ oxides grown using an $\mathrm{RF}$ sputtering system. Japanese Journal of Applied Physics, 2002, 41(2B): L212-L215.

\title{
光学设计用于全固态电致变色器件的 高溅射效率三明治结构电解质
}

\author{
贾汉祥 ${ }^{1,2}$, 郡泽伟 ${ }^{1,2}$, 黄爱涁 ${ }^{1}$, 金平实 ${ }^{1}$, 曹 逊 $^{1}$
}

(1. 中国科学院 上海硅酸盐研究所, 高性能陶瓷和超微结构国家重点实验室, 上海 200050; 2. 中国科学院大学, 北京 100049)

摘 要: 全固态电致变色器件以其光学对比度高、响应速度快以及良好的循环稳定性等特点而广泛应用于节能窗、 屏幕显示、多功能储能设备等诸多领域。然而, 传统的基于单层电解质体系的全固态电致变色器件常受限于光学透 过率和溅射效率的不足。本工作利用反应直流磁控溅射技术成功制备了基于 $\mathrm{LiAlO}_{x} / \mathrm{Ta}_{2} \mathrm{O}_{5} / \mathrm{LiAlO}_{x}(\mathrm{ATA})$ 三明治结构 电解质的全固态电致变色器件。通过引入 ATA 三明治结构电解质, 所制得的七层体系电致变色器件 (ITO/NiO/LiAlO $/ \mathrm{Ta}_{2} \mathrm{O}_{5} / \mathrm{LiAlO}_{x} / \mathrm{WO}_{3} / \mathrm{ITO}$ ) 兼具了优异的透光率和可观的㳚射效率。该全固态电致变色器件取得了令 人满意的着色效率 $\left(79.6 \mathrm{~cm}^{2} / \mathrm{C}\right.$ ), 更快的响应速度(着色时间 $1.9 \mathrm{~s}$, 褪色时间 $1.6 \mathrm{~s}$ ) 以及数百次循环的良好稳定性。此 外, ATA 三明治结构电解质充分利用了 $\mathrm{Ta}_{2} \mathrm{O}_{5}$ 优异的离子传输速率和稳定性, 并提供了足够的锂离子以满足快速变 色切换的需求。因而, 通过连续直流浌射制备的基于 ATA 三明治结构电解质的全固态电致变色器件有望为高性能 电致变色器件的量产和实际应用提供重要的指导。

关 键 词: 无机全固态; 电致变色器件; 多层电解质; 淢射效率; 光学设计

中图分类号: TQ174 文献标志码: A 